\title{
Greenhouse Gas Emissions from Plantation to the Proceeded Wood Products via State Timber Corporation Depots for Selected Tree Species using Life Cycle Assessment
}

\author{
D.K.L. Senadheera ${ }^{1}$, D.M.S.H.K. Ranasinghe ${ }^{2 *}$, W.A.S.B. Wahala ${ }^{3}$ and \\ H.S. Amarasekera ${ }^{2}$ \\ ${ }^{I}$ Carbon Consulting Company, Colombo 05, Sri Lanka \\ ${ }^{2}$ Department of Forestry and Environmental Science, University of Sri Jayewardenepura, Sri Lanka \\ ${ }^{3}$ Department of Tourism Management, Sabaragamuwa University, Sri Lanka
}

Date Received: 20-06-2015 Date Accepted: 25-09-2015

\begin{abstract}
Life Cycle Assessment (LCA) provides a methodological framework for evaluating environmental performance over the life cycle of a product, process, or an activity. In Sri Lanka, majority of timber for wood based industries comes from homegardens and Government owned forest plantations. State Timber Corporation (STC) is the authoritative body for timber harvesting in state owned forest plantations. This LCA study was carried out to calculate Greenhouse Gas (GHG) emissions of the STC timber movements from the plantation to the finished product. The study concentrated on teak, eucalypt and mahogany species as they represented fast moving commercial timber of high significance. Assessment boundary was from the harvesting to the product. Updated emission factors were used to calculate the $\mathrm{CO}_{2}$ eq units. When considering the emissions during the process, the highest was recorded in the sawmilling process (48\% from sawing, $9 \%$ from surfacing and $9 \%$ from drying). The transportation accounted for $31.25 \%$ of emissions while harvesting contributed to $6 \%$. Other indirect emissions accounted for $2.75 \%$.
\end{abstract}

Keywords: greenhouse gas emissions, embedded carbon, life cycle assessment, forest operations

\section{Introduction}

Forest ecosystems are important as sinks or sources as a function of their management and condition. It has been estimated that $680 \times 10^{6} \mathrm{tCyr}^{-1}$ is sequestered in forests (Eriksson et al., 2007). The amount of carbon in soil is globally about twice that in the atmosphere and three times as much as in the vegetation (IPCC, 2001). Thoughtful environmental professionals have long recognised that environmental loads and impacts do not begin and end with the manufacturing process. Forest harvesting for wood products alters the natural cycle of carbon. On a country scale, harvesting may significantly change the net C sink source balance related to country's forest resources and wood utilization (Winjum et al., 1998). Harvesting influences the soil organic carbon stock. A decline in soil organic carbon following harvesting is commonly assumed because of decreasing litter input and

\footnotetext{
*Correspondence: hemanthi.ranasinghe@gmail.com
} Tel: +94718538975

ISSN 2235-9370 Print/ISSN 2235-9362 Online (C) University of Sri Jayewardenepura 
possibly an increased decomposition rate. As a consequence, over a period of about two decades, lifecycle assessment (LCA) methodology has been developed with the objective of providing a framework for comprehensive evaluations of resource consumption and environmental emissions associated with the production, use, and disposal of products.

The LCA studies in forestry and forest products sector is very limited especially due to the traditional thinking that forestry is already environmentally friendly due to the biological production and the wide variety of positive ecological and sociological functions of forest ecosystems. However, the use of agrochemicals in plantation establishment, forest harvesting, processing etc. involved in a forest product emits a considerable amount of greenhouse gases and attempts could be made to minimise these emissions using LCA studies. A life cycle analysis for wood begins with the planting to harvesting trees and ends with the disposal of wood products made from those trees. Two parallel and related streams of GHG impacts result directly from the harvesting, processing, use and disposal of wood products. Firstly, carbon is lost at each step of the processing chain due to the physical breakdown of wood, releasing carbon dioxide, methane and other by-products. Secondly, the transportation of wood to mills, transforming into varieties of products and delivery to customers and eventually to landfills (Gower, 2003).

According to the Forest Inventory Database (FORDATA) of the Forest Department Sri Lanka, forest plantations are distributed over 17 forest divisions, which are largely based on administrative districts, covering all three major climatic zones (i.e., intermediate and dry zones). The database lists $86,363.8$ ha of forest plantations in the country. The majority of the forest plantations, except for those in the northern and eastern provinces have been mapped and inventoried. The State Timber Corporation is the official designated entity to harvest these forests. Therefore the main objective of the study was to estimate the greenhouse gas (GHG) emissions of the main processors considering STC as the focal entity using LCA method with a view to provide recommendations for minimising GHG emissions.

\section{Methodology}

Three timber species were selected for this study based on the largest plantations, largest timber volume movements and having key commercial value in the state sector. The boundary of the study was from the plantation (harvesting), transport and processing for the finished product. Teak and eucalypt timber came from the state owned plantations located in Anuradhapura, Kurunegala, Kandy, Ampara, Moneragala and Polonnaruwa (for teak) and Nuwara Eliya and Badulla (for eucalypt) while Mahogany logs came from mostly homegardens. Timber stock movements and transportation data of timber species were obtained from STC Regional Timber Depots.

\subsection{Wood material flow analysis}

The flow of the wood material was analysed in each stage of the conversion. Generated waste and the by-products were separately quantified and the process conversions were examined. Wooden biomass was weighted in each stage. Wood volume passed through the process was weighed and the residuals which were separated as left overs, recyclable materials and waste was weighed separately to conduct the wood material flow in selected unit. 


\subsection{GHG emission calculation}

Greenhouse gas emissions of the main processors were estimated considering STC as the focal entity and the boundary was harvesting point to the timber depots and the finished product. Figure 1 shows the operational boundary of the study. GHG emissions were estimated in each identified functional unit. Activity data shown in the Table 1 were collected by conducting sample surveys in selected timber depots.

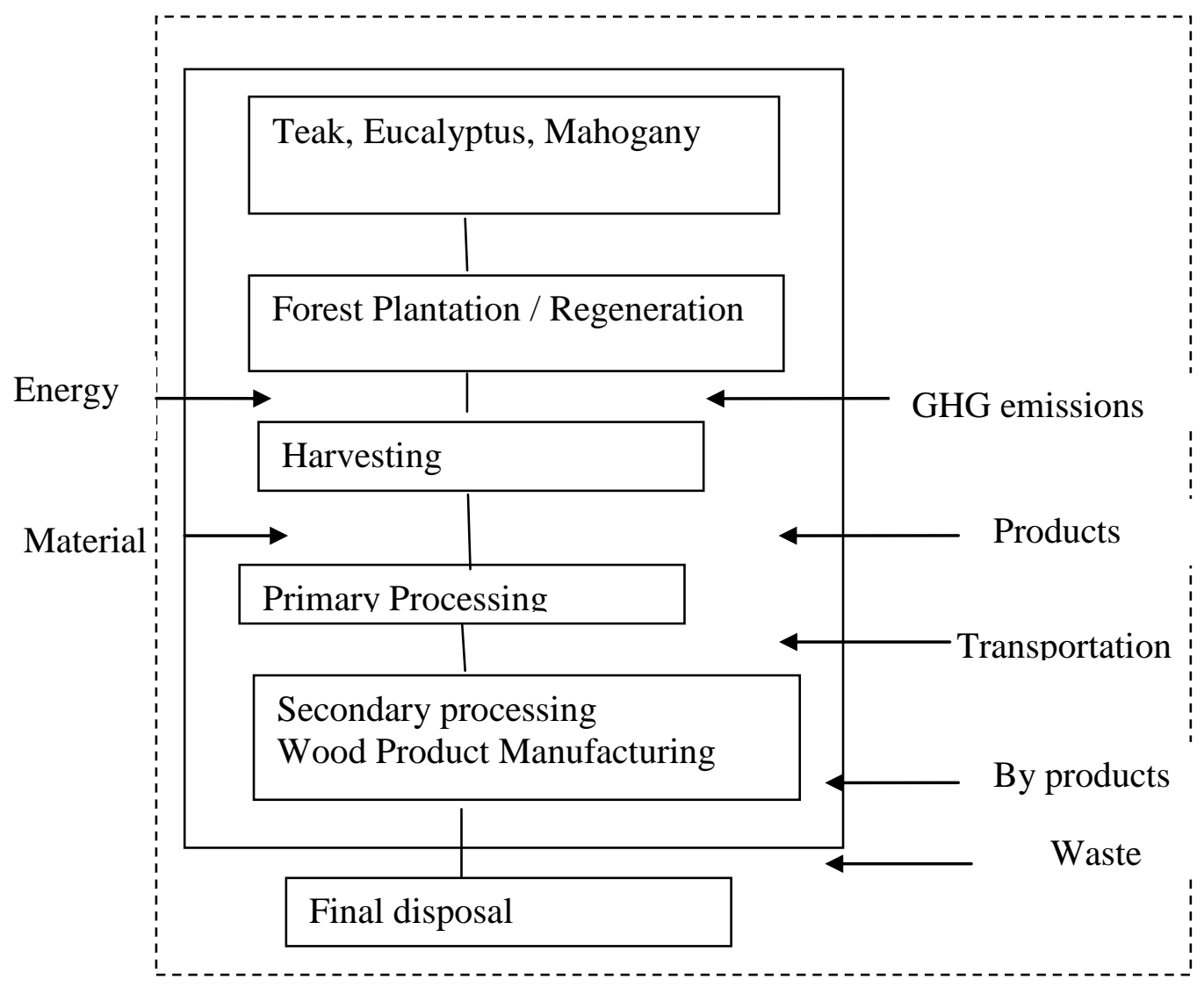

Figure 1: Carbon flow process and emission sources identification within the system boundary.

Table 1: Inventory data collected from Sri Lanka Forest Department.

\begin{tabular}{ll}
\hline Process & Inventory Data \\
\hline Felling Process & $\begin{array}{l}\text { Average age of the log, Thinning practices, Type of machine used to } \\
\text { harvest, Working hours, Type of fuel and the fuel consumption }\end{array}$ \\
Transportation & Mode of transportation, Type of fuel, Fuel consumption, Mileage \\
Sawmill & $\begin{array}{l}\text { Type of machines used, Working hours of the machines, Volume of } \\
\text { the products, Type of fuel used and its consumption, Electricity } \\
\text { Consumption }\end{array}$ \\
\hline
\end{tabular}

The LCA was done following the basic principles of ISO 14040 and ISO 14044. The global warming potential was calculated using the values of the IPCC Fourth Assessment Report (2007). The results were analysed with Centre of Environmental Science (CML) methodology stated in the LCA operational guide to the OSO standard (Guinée et al., 2001). 
The system boundary defines the unit processes to be included in the system. The unit systems included were inputs and outputs in the main manufacturing/processing sequence, distribution/ transportation, production and use of fuels, electricity and heat and manufacture of ancillary materials.

$\mathrm{CO}_{2}$ emission factors were sourced from the Department of Food and Rural Affairs (DEFRA) emission factor data base, the International Energy Agency (2010), the U.S. Environmental Protection Agency Inventories (2008/2013) and the IPCC Guidelines for National Greenhouse Gas Inventories 2006. Updated emission factors were used to calculate the $\mathrm{CO}_{2}$ eq units. Table 2 shows the global warming potential in each GHG gas according to the fourth assessment report of the IPCCC.

Table 2: Global Warming Potential, according to the fourth assessment report published by IPCCC.

\begin{tabular}{lll}
\hline Greenhouse Gas & Chemical Formula & GWP \\
\hline Carbon dioxide & $\mathrm{CO}_{2}$ & 1 \\
Methane & $\mathrm{CH}_{4}$ & 25 \\
Nitrous oxide & $\mathrm{N}_{2} \mathrm{O}$ & 298 \\
Hydro fluorocarbons & $\mathrm{HFCs}$ & $124-14,800$ \\
Per fluorocarbons & $\mathrm{PFCs}$ & $7,390-12,200$ \\
Sulphur hexafluoride & $\mathrm{SF}_{6}$ & 22,800 \\
\hline
\end{tabular}

Methane and Nitrous Oxide emission factors for grid electricity were derived from the national grid, mix compositions from the Sustainable Energy Authority, Sri Lanka (2013) and International Energy Agency (2010) and the Intergovernmental Panel on Climate Change (2006) for electricity.

In addition to that, Emission Factor Data Base (EFDB) software developed by IPCC was used to obtain relevant Emission Factors to calculate GHG sources. Following generalized equation was used to calculate GHG emissions for each identifies emission sources.

Total Emissions =

Activity data $\times \mathrm{CO} 2$ emission factor $\times 1+$ Activity data $\times \mathrm{CH} 4$ emission factor $\times 21+$ Activity data $\times$ N20 emission factor $\times 310$

\section{Results}

\subsection{Material flow analysis}

In the primary processing, logs removed from the harvested sites represented approximately $60 \%$ of the total volume, hence the storage carbon. It was estimated that $10 \%$ was taken as fuel wood, $5 \%$ as leftovers at the harvesting site, $23 \%$ at the primary processing stage and $2 \%$ at the secondary processing stage.

\subsection{GHG emissions}

When considering the total emissions during the process, $6 \%$ emissions were from harvesting while transportation accounted for are approximately 31.25\%. Sawmilling was the highest GHG emitting sub process contributing $48 \%$ from sawing and $9 \%$ from surfacing and $9 \%$ was drying. Other indirect emissions accounted for $2.75 \%$ (Figure 2). 


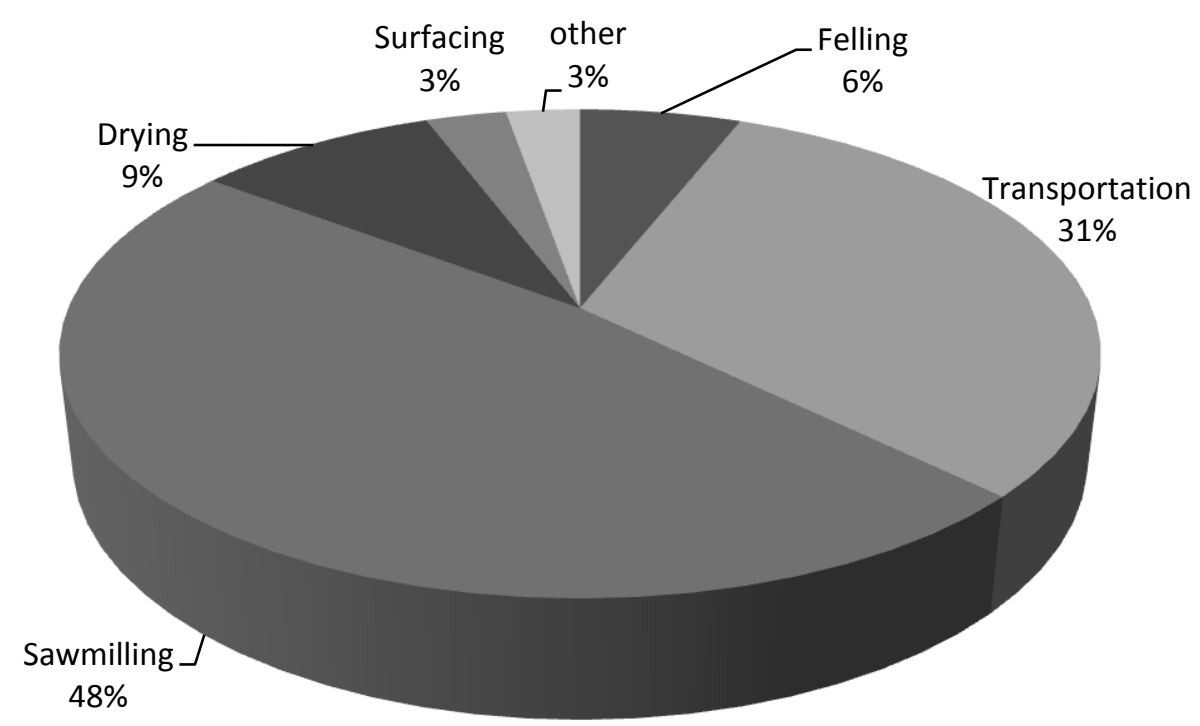

Figure 2: Percentage contribution of GHG emissions of state timber corporation's operations.

\section{Discussion}

In the present study, the highest emissions were involved in the timber processing which included sawing (48\%), surfacing (9\%) and drying (9\%) followed by transportation (32\%), harvesting $(6 \%)$ and then other indirect emissions (3\%). Results of similar nature were recorded by Peuttmann and Bowyer (2002) in USA where $25 \%$ out of the total GHG emissions was due to drying of lumber. This was also endorsed by the findings of Wilson (2005) who reported that up to $92 \%$ of the energy in the lumber and veneer manufacture was spent on kiln-drying. In the present study, the total GHG emissions in the drying process was $9 \%$ and the main reason for the reduced figure in the present study was that State Timber Corporation use air drying against kiln drying which uses less energy. On average, transportation accounted for the next high GHG emissions in the present study and this could be due to many factors including the distance between the plantation to the depot, the conditions of the vehicles, the lack of transport planning etc. In a study on GHG emissions from the use of primary energy in forest operations and long distance transportation of timber in Finland, Karjalainen and Asikainen (1996) reported that from the total emissions of $424.2 \mathrm{Gg}$ carbon dioxide, forest improvement work accounted for $8 \%$, cutting of timber $13 \%$, haulage $18 \%$ and long distance transportation 57\%. Findings of the present study were also in agreement with the trend where the emissions from sawmilling and transportation recorded highest compared with harvesting. As the plantation management of the different species was not taken into account, there was no significant differentiation observed between the plant species used in the study.

\section{Conclusion}

Use of air drying against kiln drying reduced the emissions significantly. However, the large electricity consumption during the sawmilling sub process increases GHG emissions. The type and condition of the equipment in the sawmills and resorting to cleaner fuels could reduce the GHG emissions in the sawmilling stage. Locating new depots close to existing plantations may reduce the transportation cost significantly and reduce the GHG emissions. 


\section{References}

Amarasekera, H.S. 1996. Alternative timber species: A review of their properties and uses. Forestry for Development, Proceedings of Annual Forestry Symposium 1995, Depart. of Forestry \& Env. Sci., Univ. of Sri Jayewardenepura, Sri Lanka.

Eriksson, E., Gillesple, A.R., Gustavsson, L, Langvall, O, Olsson, M. Sathre, R. and Stendhal, J. 2007. Integrated carbon analysis of forest management practices and wood substitution, Canadian Journal of Forest Research, 37(3): 671-681.

Gielen, D., Kram, T. and Brezet. H. 1999. Integrated energy and materials scenarios for Greenhouse Gas emission mitigation. IEA/DOE/EPA workshop on Technologies to Reduce GHG Emissions: Engineering-Economic Analysis of Conserved Energy and Carbon. May 5-7, Washington DC, USA.

Gower, S.T.A, McKeon-Ruedifer, Reitter, A., Bradly, M., Refkin, D.J., Tollefson, T., Souba, F.J., Taup, A., Embury-Williams, L., Schiavone, S., Weinbauer, A.C., Janetos, A. and Jarvis, R. 2003. Following the paper trails: The impacts of Magazine and Dimensional Lumber Production on case study. The H. John Heins III Centre for Science, Economics and the Environment, Washington D.C.

Gower, S. 2003. Patterns and mechanism of the forest carbon cycle. Annual review of Environmental Resources 28: 169-204.

Guinee, J.B., Bruijn H. De., Duin, R.V., Huijbregts, M.A.J. 2001. Report of a Danish-Dutch workshop on LCA methodologies, 16-17 September 1999 at CML, Leiden.

International Energy Agency. 2010. World energy outlook. International Energy Agency, France.

Inventory of U.S. Greenhouse Gas Emissions and Sinks: 1990-2013 (April 2015) [http://www3.epa. gov/climatechange/ghgemissions/usinventoryreport.html\#fullreport]

Intergovernmental Panel on Climate Change. 2006. IPCCC guidelines for national greenhouse gas inventories. Japan Institute for Global Environmental Strategies (IGES) for the IPCCC.

Johnson, L., Lippke, B., Marshall, J.D., and Comnick, J. 2005. Life cycle impacts of forest resources activities in the Pacific Northwest and Southeast United States. Wood and Fibre Science 37: 3046.

Karjalainen, T., Pussinen, A. 1994. Role of wood based products in absorbing atmospheric carbon. Silva Fennica 28 (2): 67-80.

Kinj, Ohuchi, T., Kii, H., Murase, Y. 2005. Studies on life cycle assessment of Sugi Lumber. Journal of Faculty of Agriculture of Kyushu University, 50(2): 343-351.

MacKeever, A. and Anderson, A., 1998. Timber products used to build US single family houses, Forest Product Journal 42(4): 11-18.

Miner, R.A. and Lucier, A.A. 1994. Life cycle assessment: Considerations in performing life cycle assessments on forest products. Environmental Toxicology and Chemistry 13(8): 1375-1380.

Nunery, J.S. and Keeton, W.S. 2010. Forest carbon storage in the northeastern United States: Net effects of harvesting frequency, post-harvest retention, and wood products. Forest Ecology and management, 259(8): 1363-1375.

Puettmann, M.E. 2000. Environmental life cycle assessment of southern pine lumber treated with borate wood preservatives. Ph.D Thesis, University of Minnesota. St. Paul, Minnesota.

Sustainable Energy Authority, Sri Lanka (2013), Grid emission factors. [http://www.info.energy.gov. $1 \mathrm{k} /]$

Winjum, JK, Brown, S. and Schlamadinger, B. 1998. Forest harvest and wood products: Sources and sinks of atmospheric carbon dioxide. Forest Science, 42(2): 272-284. 